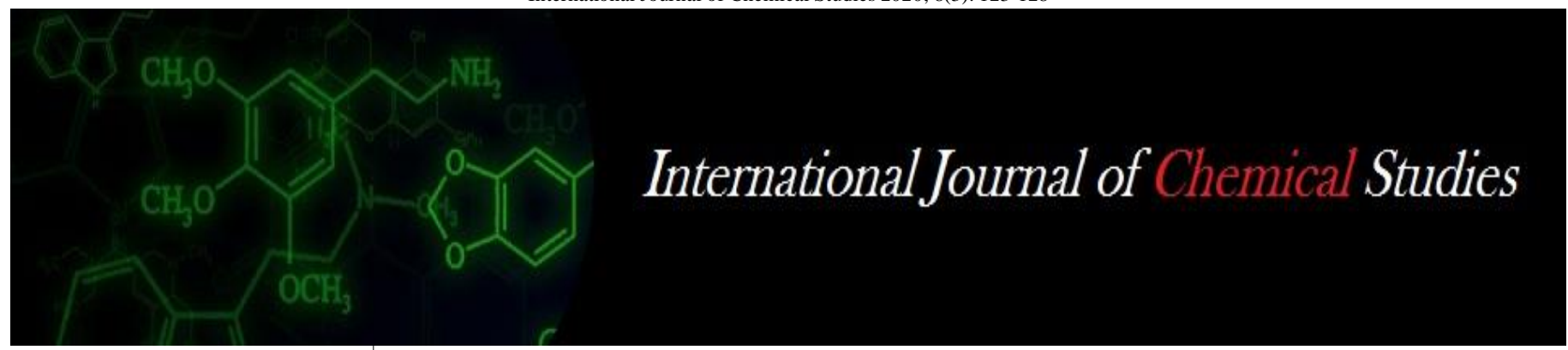

P-ISSN: 2349-8528

E-ISSN: 2321-4902

www.chemijournal.com

IJCS 2020; 8(3): 123-128

(C) 2020 IJCS

Received: 10-03-2020

Accepted: 12-04-2020

U Nagabhushanam

Senior Scientist (Agronomy)

Regional Agricultural

Research Station, Warangal,

Telangana, India

P Spandana Bhatt

Scientist (Agronomy), Rice

Research Centre, Rajendranagar,

Hyderabad, Telangana, India

Corresponding Author:

U Nagabhushanam

Senior Scientist (Agronomy)

Regional Agricultural

Research Station, W arangal,

Telangana, India

\section{Effect of neem coated urea on yield attributes, yield, nutrient uptake and economics of rice (Oryza sativa L.)}

\section{U Nagabhushanam and P Spandana Bhatt}

DOI: https://doi.org/10.22271/chemi.2020.v8.i3b.9213

\begin{abstract}
A field experiment was carried out during the Kharif, 2017 at Rice Research Centre, Agricultural Research Institute, Rajendranagar, Hyderabad (TS), India to study the "Effect of Neem coated urea on yield attributes, yield, nutrient uptake and economics of rice (Oryza sativa L)". The experiment was laid out in Randomized complete block design with three replications and eight treatments viz., $\mathrm{T}_{1}$ - RDF 12060-40 N through Prilled urea (PU), $\mathrm{T}_{2}-\mathrm{RDF} 120-60-40 \mathrm{~N}$ through Neem coated urea (NCU), $\mathrm{T}_{3}-95 \%$ Recommended dose of nitrogen (RDN) through NCU + Recommended dose of Phosphorus and Potassium (RDP and K), T4- 90\% Recommended dose of nitrogen (RDN) through NCU + Recommended dose of Phosphorus and Potassium(RDP and K), $\mathrm{T}_{5}-85 \%$ Recommended dose of nitrogen (RDN) through NCU + Recommended dose of Phosphorus and Potassium(RDP and K), T6-80\% Recommended dose of nitrogen (RDN) through NCU + Recommended dose of Phosphorus and Potassium(RDP and K), T7- 75\% Recommended dose of nitrogen (RDN) through NCU + Recommended dose of Phosphorus and Potassium(RDP and K) andT 8 - 0 Nitrogen + Recommended dose of Phosphorus and Potassium(RDP and $\mathrm{K})$ (Control). The results showed that $\mathrm{T}_{2}$ RDF 120-60-40 N through Neem coated urea (NCU) produced higher grain, straw yields and $\mathrm{BC}$ ratio whereas, $\mathrm{T}_{3}-95 \%$ Recommended dose of nitrogen (RDN) through $\mathrm{NCU}+$ Recommended dose of Phosphorus and Potassium (RDP and K) with 5\% reduction in recommended nitrogen in NCU form produced the similar yields of grain and straw, BC ratio which were obtained in $\mathrm{T}_{2}$ - RDF 120-60-40 N through Neem coated urea (NCU). Hence, $\mathrm{T}_{3}-95 \%$ Recommended dose of nitrogen (RDN) through NCU + Recommended dose of Phosphorus and Potassium (RDP and K) with $5 \%$ saving in recommended nitrogen in NCU form proved to be better for higher productivity and profitability of rice.
\end{abstract}

Keywords: Rice, nitrogen, neem coated urea, yield

\section{Introduction}

Rice (Oryza sativa L.,) is one of the most important and widely cultivated cereal crops grown in world. Of the total global rice production, $90 \%$ was produced and consumed in Asia and south East Asia. It is not only staple food crop of Indian subcontinent, but also more than $40 \%$ of calorie requirement met from the rice. In Asia, India has the largest area under rice $(43.4 \mathrm{~m}$ ha) accounting for $29.4 \%$ of the global rice area with a total production of $104.3 \mathrm{~m} \mathrm{t}$ and productivity of $2137 \mathrm{~kg} / \mathrm{ha}$ (Ministry of Agriculture and Farmer Welfare, 2015) during 201516. In Telangana State, rice occupies an average area of $2 \mathrm{~m}$ ha area and production of $6.62 \mathrm{~m} \mathrm{t}$ with an average productivity $3290 \mathrm{~kg} / \mathrm{ha}$ (Statistical year book, 2015)

Among the 17 essential nutrients required by crop plants for their normal growth, development and higher yields nitrogen is generally required by them in the largest amount. Urea is one of the most widely used sources of nitrogen fertilizer in the world. It also has high nitrogen content (46\%), lower production costs as comparison to other popular nitrogen sources. Of late, the partial factor productivity of fertilizers has been declining as evident from stagnant food grain production despite increased fertilizer use in the country, thereby lowering the nitrogen use efficiency. The causes of low nitrogen use efficiency (NUE) include losses due to volatilization as ammonia, leaching, denitrification in flooded condition, run off, fixation as non exchangeable $\mathrm{NH}_{4}{ }^{+}$and immobilization by soil microbes. The unrecovered nitrogen constitutes a potential contributor to ground water contamination, acid rain and global 
warming, slow release nitrogen fertilizers offer a solution to this problem by releasing small amounts of nitrogen coinciding with the crop need and increasing the efficiency of nitrogen by minimizing it's losses. Slow release nitrogen fertilizers reduce the losses of fertilizer application, cause reduction in stress and specific toxicity and reduce environmental pollution. Hence, in 2015, the Government of India directed that all fertilizer urea manufactured in the country or imported will have to be coated with neem oil at the rate of $0.5 \mathrm{~kg}$ per tonne. This decision was motivated not only by better performance of neem oil coated urea via uncoated urea but also by an expectation that it will lead to reduced consumption of urea. Increasing nitrogen use efficiency means reducing the nitrogen losses through leaching, immobilization and reducing ground water pollution by nitrates as well as ammonia gas pollution in the air, it also reduces import of costly fertilizers as well as reduces ground water and soil pollution. Nitrification inhibiting properties of neem and its role in increasing NUE in rice was first reported by Bains et al. (1971) [1]. It's necessary to standardize the quantity of neem coated urea with comparison to prilled urea. Keeping in view, the present experiment was conducted to determine the neem coated urea requirement of flooded rice for higher crop yield.

\section{Material and methods}

A field experiment was carried out during the Kharif, 2017 at Rice Research Centre, Agricultural Research Institute, Professor Jayashankar Telangana State Agricultural University Rajendranagar, Hyderabad. (TS) to study the "Effect of Neem coated urea on yield attributes, yield, nutrient uptake and economics of rice (Oryza sativa L.,)". The experimental site is located at $17^{0} 19^{1}$ North latitude and $78^{0} 23^{1}$ East Longitude and $542.6 \mathrm{~m}$ above mean sea level. The soil of experimental site is clay loam in texture, low in available N $170 \mathrm{~kg} / \mathrm{ha}$ (Subbaiah and Asija, 1956) ${ }^{[16]}$, high in available P $82 \mathrm{~kg} / \mathrm{ha}$ (Olsen et al, 1954) and available K 368 $\mathrm{kg} / \mathrm{ha}\left(1 \mathrm{~N} \mathrm{NH} \mathrm{NAC}_{4}\right.$ - extractable $\mathrm{K}$ ) with neutral in reaction (pH 7.3) and electrical conductivity $0.26 \mathrm{ds} / \mathrm{m}$. The test variety RNR-15048 (Telangana Sona) was sown in first fortnight of July, planted in first fortnight of August with a spacing of $15 \times 15 \mathrm{~cm}$. The experiment was laid out in a Randomized complete block design with three replications and eight treatments i.e., $\mathrm{T}_{1}-\mathrm{RDF}$ 120-60-40 N through Prilled urea (PU), T2- RDF 120-60-40 N through Neem coated urea (NCU), $\mathrm{T}_{3}-95 \%$ Recommended dose of nitrogen (RDN) through NCU + Recommended dose of Phosphorus and Potassium(RDP and $\mathrm{K}$ ), $\mathrm{T}_{4}-90 \%$ Recommended dose of nitrogen (RDN) through NCU + Recommended dose of Phosphorus and Potassium(RDP and $\mathrm{K}$ ), $\mathrm{T}_{5^{-}} \quad 85 \%$ Recommended dose of nitrogen (RDN) through NCU + Recommended dose of Phosphorus and Potassium (RDP and $\mathrm{K}), \mathrm{T}_{6}-80 \%$ Recommended dose of nitrogen (RDN) through $\mathrm{NCU}+$ Recommended dose of Phosphorus and Potassium(RDP and $\mathrm{K}$ ), $\mathrm{T}_{7-}$ 75\% Recommended dose of nitrogen (RDN) through NCU + Recommended dose of Phosphorus and Potassium(RDP and K) and $\mathrm{T}_{8}-0$ Nitrogen + Recommended dose of Phosphorus and Potassium(RDP and $\mathrm{K})$ (Control). The treatment means were compared using least significant difference at $5 \%$ level of significance (Gomez and Gomez, 1984) ${ }^{[2]}$. The economics were also calculated on the basis of cost of cultivation, gross returns, net returns and benefit cost ratio. The cost of cultivation for each treatment was calculated by summing all the variable cost items in the production process. Similarly, gross returns were calculated based on prevailing market price of the produce. The net returns were obtained after deducting the cost of cultivation from gross returns. Thus the benefit cost analysis was obtained by dividing total returns from a unit with total cost of a unit.

\section{Results and Discussion \\ Effect of neem coated urea on growth character of rice}

Plant height being an important growth parameter was influenced significantly with application of nitrogen either in the form of neem coated urea or prilled urea as compared to non application of nitrogen with recommended dose of phosphorus and potassium. Plant height recorded significantly higher with $\mathrm{T}_{2}-\mathrm{RDF} 120-60-40 \mathrm{~N}$ through Neem coated urea (NCU) $(103.7 \mathrm{~cm})$ over $\mathrm{T}_{8^{-}} 0$ Nitrogen + Recommended dose of Phosphorus and Potassium (RDP and K) (Control) followed by $\mathrm{T}_{1}$ - RDF 120-60-40 N through Prilled urea (PU) $(100.0 \mathrm{~cm}), \mathrm{T}_{3}-95 \%$ Recommended dose of nitrogen (RDN) through NCU + Recommended dose of Phosphorus and Potassium(RDP and K) $(103.0 \mathrm{~cm}), \mathrm{T}_{4^{-}} 90 \%$ Recommended dose of nitrogen (RDN) through NCU + Recommended dose of Phosphorus and Potassium (RDP and K) $(102.3 \mathrm{~cm}), \mathrm{T}_{5^{-}}$ $85 \%$ Recommended dose of nitrogen (RDN) through NCU + Recommended dose of Phosphorus and Potassium(RDP and K) $(102.0 \mathrm{~cm}), \mathrm{T}_{6}-80 \%$ Recommended dose of nitrogen (RDN) through NCU + Recommended dose of Phosphorus and Potassium (RDP and $\mathrm{K})(101.7 \mathrm{~cm}), \mathrm{T}_{7^{-}} \quad 75 \%$ Recommended dose of nitrogen (RDN) through NCU + Recommended dose of Phosphorus and Potassium (RDP and $\mathrm{K})(101.3 \mathrm{~cm})$. Lowest plant height was recorded in $\mathrm{T}_{8^{-}} 0$ Nitrogen + Recommended dose of Phosphorus and Potassium (RDP and K) (Control) (196.7). However, $\mathrm{T}_{1}, \mathrm{~T}_{2}, \mathrm{~T}_{3}, \mathrm{~T}_{4}, \mathrm{~T}_{5}$, $\mathrm{T}_{6}$ and $\mathrm{T}_{7}$ are comparable to each other as indicated in Table.1. Similar results were also observed by Prasad et al. (1998) ${ }^{[9]}$, Kumar et al. (2015) ${ }^{[6]}$.

\section{Effect of neem coated urea on yield attributing characters of rice}

The number of tillers $/ \mathrm{m}^{2}$ was influenced significantly with application of different nitrogen levels in the form of neem coated urea or prilled urea as compared to non application of nitrogen with recommended dose of phosphorus and potassium (Table.1)

The number of tillers $/ \mathrm{m}^{2}$ was significantly higher in T2- RDF $120-60-40 \mathrm{~N}$ through Neem coated urea (NCU) (392.7) over $\mathrm{T}_{5}-85 \%$ Recommended dose of nitrogen (RDN) through $\mathrm{NCU}+$ Recommended dose of Phosphorus and Potassium (RDP and K) (343.0), $\mathrm{T}_{6}-80 \%$ Recommended dose of nitrogen (RDN) through NCU + Recommended dose of Phosphorus and Potassium (RDP and K) (333.0), $\mathrm{T}_{7-}$ 75\% Recommended dose of nitrogen (RDN) through NCU + Recommended dose of Phosphorus and Potassium (RDP and K) (316.0). Lowest plant height was recorded in $\mathrm{T}_{8^{-}} 0$ Nitrogen + Recommended dose of Phosphorus and Potassium (RDP and K) (Control) $(81.7 \mathrm{~cm})$. Lowest number of tillers $/ \mathrm{m}^{2}$ was recorded in $\mathrm{T}_{8}-0$ Nitrogen + Recommended dose of Phosphorus and Potassium (RDP and K) (Control) (196.7) (Table.1). These results were akin to the results reported by Prasad et al. (1998) ${ }^{[9]}$, Kumar et al. (2015) ${ }^{[6]}$ and Raj et al. (2014) ${ }^{[11]}$ also found similar findings.

The number of panicles $/ \mathrm{m}^{2}$ was influenced significantly with application of different nitrogen levels. The number of panicles $/ \mathrm{m}^{2}$ was significantly higher in $\mathrm{T}_{2}$ - RDF $120-60-40 \mathrm{~N}$ through Neem coated urea (NCU) (357.7) over $\mathrm{T}_{5}-85 \%$ Recommended dose of nitrogen (RDN) through NCU + 
Recommended dose of Phosphorus and Potassium (RDP and K) (320.7), $\mathrm{T}_{6}-80 \%$ Recommended dose of nitrogen (RDN) through NCU + Recommended dose of Phosphorus and Potassium (RDP and K) (305.3), $\mathrm{T}_{7-}$ 75\% Recommended dose of nitrogen (RDN) through NCU + Recommended dose of Phosphorus and Potassium (RDP and K) (286.3) and $\mathrm{T}_{8^{-}} 0$ Nitrogen + Recommended dose of Phosphorus and Potassium (RDP and K) (Control) (168.0) and it remained comparable with $\mathrm{T}_{1}$ - RDF 120-60-40 N through Prilled urea (PU) (344.0), $\mathrm{T}_{3^{-}}$-95\% Recommended dose of nitrogen (RDN) through $\mathrm{NCU}+$ Recommended dose of Phosphorus and Potassium (RDP and K) (354.3) and $\mathrm{T}_{4}-90 \%$ Recommended dose of nitrogen (RDN) through NCU + Recommended dose of Phosphorus and Potassium (RDP and K) (337.0). Lowest number of panicles $/ \mathrm{m}^{2}$ was recorded in $\mathrm{T}_{8^{-}} 0$ Nitrogen + Recommended dose of Phosphorus and Potassium (RDP and K) (Control) (168.0). Similar findings were reported by Kumar et al. (2015) ${ }^{[6]}$, he observed that neem coated urea performed better which increased the growth and yield attributes i.e. plant height, number of tillers $/ \mathrm{m} 2$, number of panicles $/ \mathrm{m}^{2}$, number of grains/panicles (Table.1). Prasad et al., (1998) [9], Kumar et al. (2015) [6] also found similar findings. Pushpanathan et al. (2005) found coated fertilizers improved the yield components.

The panicle length was significantly influenced with application of different levels of nitrogen. The panicle length was recorded significantly higher in $\mathrm{T}_{2}-\mathrm{RDF} 120-60-40 \mathrm{~N}$ through Neem coated urea (NCU) $(27.9 \mathrm{~cm})$ over $\mathrm{T}_{1}-\mathrm{RDF}$ $120-60-40 \mathrm{~N}$ through Prilled urea (PU) $(26.9 \mathrm{~cm}), \mathrm{T}_{4}-90 \%$ Recommended dose of nitrogen (RDN) through NCU + Recommended dose of Phosphorus and Potassium(RDP and K) $(26.8 \mathrm{~cm}), \mathrm{T}_{5}-85 \%$ Recommended dose of nitrogen (RDN) through NCU + Recommended dose of Phosphorus and Potassium (RDP and K) $(26.4 \mathrm{~cm}), \mathrm{T}_{6}-80 \%$ Recommended dose of nitrogen (RDN) through NCU + Recommended dose of Phosphorus and Potassium (RDP and $\mathrm{K})(26.1 \mathrm{~cm}), \mathrm{T}_{7-}$ $75 \%$ Recommended dose of nitrogen (RDN) through NCU + Recommended dose of Phosphorus and Potassium (RDP and $\mathrm{K})(25.3 \mathrm{~cm})$ and $\mathrm{T}_{8^{-}} 0$ Nitrogen + Recommended dose of Phosphorus and Potassium (RDP and K) (Control) $(20.7 \mathrm{~cm})$ (Table.1). Similar findings were reported by Kumar et al. $(2015)^{[6]}$, he revealed that neem coated urea performed better which increased the growth and yield attributes i.e. plant height, number of tillers $/ \mathrm{m}^{2}$, number of panicles $/ \mathrm{m}^{2}$, panicle length, panicle weight number of grains/panicles. Kumar et al. (2015) ${ }^{[6]}$ and Raj et al. (2014) ${ }^{[11]}$ also found similar findings.

Panicle weight was influenced significantly with application of different nitrogen levels. The panicle weight was recorded significantly higher in $\mathrm{T}_{2}-\mathrm{RDF} 120-60-40 \mathrm{~N}$ through Neem coated urea (NCU) (4.5g) over $\mathrm{T}_{8^{-}} \quad 0$ Nitrogen + Recommended dose of Phosphorus and Potassium (RDP and $\mathrm{K}$ ) (Control) (1.3g) and it remained comparable with T1- RDF 120-60-40 N through Prilled urea (PU) (4.3g), $\mathrm{T}_{3}-95 \%$ Recommended dose of nitrogen (RDN) through NCU + Recommended dose of Phosphorus and Potassium (RDP and K) (4.4g) and $\mathrm{T}_{4^{-}}$90\% Recommended dose of nitrogen (RDN) through NCU + Recommended dose of Phosphorus and Potassium (RDP and K) $(4.1 \mathrm{~g}), \mathrm{T}_{5^{-}} 85 \%$ Recommended dose of nitrogen (RDN) through NCU + Recommended dose of Phosphorus and Potassium (RDP and K) (4.0 g), $\mathrm{T}_{6}-80 \%$ Recommended dose of nitrogen (RDN) through NCU + Recommended dose of Phosphorus and Potassium (RDP and $\mathrm{K})(4.0 \mathrm{~g}), \mathrm{T}_{7-}$ 75\% Recommended dose of nitrogen (RDN) through NCU + Recommended dose of Phosphorus and
Potassium (RDP and K) (3.9 g) (Table 1). Neem coated urea supply nutrient to the plant and reduced the losses of nitrogen in soil. Similar findings were reported by Kumar et al., (2015) [6], he suggested that neem coated urea performed better which increased the growth and yield attributes i.e. plant height, number of tillers $/ \mathrm{m}^{2}$, number of panicles $/ \mathrm{m}^{2}$, panicle length, panicle weight number of grains/panicles (Kumar et al., 2007) ${ }^{[5]}$.

Test weight significantly influenced with application of different levels of nitrogen. Test weight was recorded significantly higher in $\mathrm{T}_{2}-\mathrm{RDF} 120-60-40 \mathrm{~N}$ through Neem coated urea (NCU) (12.75 g) over $\mathrm{T}_{1-}$ RDF 120-60-40 N through Prilled urea (PU) $(11.89 \mathrm{~g}), \mathrm{T}_{6}-80 \%$ Recommended dose of nitrogen (RDN) through NCU + Recommended dose of Phosphorus and Potassium (RDP and K) (11.61 g), $\mathrm{T}_{7^{-}}$ 75\% Recommended dose of nitrogen (RDN) through NCU + Recommended dose of Phosphorus and Potassium (RDP and K) $(11.24 \mathrm{~g})$ and $\mathrm{T}_{8}-0$ Nitrogen + Recommended dose of Phosphorus and Potassium (RDP and K) (Control) (10.24g) and it was comparable with $\mathrm{T}_{3}-95 \%$ Recommended dose of nitrogen (RDN) through NCU + Recommended dose of Phosphorus and Potassium (RDP and $\mathrm{K})(12.17 \mathrm{~g})$ and $\mathrm{T}_{4}-$ 90\% Recommended Dose of nitrogen (RDN) through NCU + Recommended dose of Phosphorus and Potassium (RDP and K) $(11.97 \mathrm{~g}), \mathrm{T}_{5}-85 \%$ Recommended dose of nitrogen (RDN) through NCU + Recommended dose of Phosphorus and Potassium (RDP and K) (11.97 g), lowest test weight was recorded in $\mathrm{T}_{8^{-}} 0$ Nitrogen + Recommended dose of Phosphorus and Potassium (RDP and K) (Control) (10.24 g) (Table.1). These results are in conformity with findings of Pushpanathan et al. (2005), he observed that application of neem coated fertilizers improved the yield components like productive tillers, panicle length, fertile spikelets/panicle and 1000 seed weight. These results are also corroborate with findings of Kumar et al., (2011) ${ }^{[4]}$.

\section{Effect of neem coated urea on Grain and straw yield of rice}

The grain yield was influenced significantly with application of different levels of nitrogen either in the form of neem coated urea or prilled urea as compared to non application of nitrogen with recommended dose of phosphorus and potassium. The grain yield recorded significantly higher with respect to $\mathrm{T}_{2}-\mathrm{RDF} 120-60-40 \mathrm{~N}$ through Neem coated urea (NCU) $(8029 \mathrm{~kg} / \mathrm{ha})$ as compared to $\mathrm{T}_{4^{-}} 90 \%$ Recommended dose of nitrogen (RDN) through NCU + Recommended dose of Phosphorus and Potassium (RDP and K) (7052 kg/ha), $\mathrm{T}_{5^{-}}$ $85 \%$ Recommended dose of nitrogen (RDN) through NCU + Recommended dose of Phosphorus and Potassium (RDP and K) $(6754 \mathrm{~kg} / \mathrm{ha}), \mathrm{T}_{6}-80 \%$ Recommended dose of nitrogen (RDN) through NCU + Recommended dose of Phosphorus and Potassium (RDP and K) (6442 kg/ha), $\mathrm{T}_{7^{-}} \quad 75 \%$ Recommended dose of nitrogen (RDN) through NCU + Recommended dose of Phosphorus and Potassium (RDP and K) $(5983 \mathrm{~kg} / \mathrm{ha}) \cdot \mathrm{T}_{8}-0$ Nitrogen + Recommended dose of Phosphorus and Potassium (RDP and K) (Control) (2947 $\mathrm{kg} / \mathrm{ha}$ ) and it remained comparable with $\mathrm{T}_{1}-\mathrm{RDF} 120-60-40$ $\mathrm{N}$ through Prilled urea (PU) (7565 kg/ha), $\mathrm{T}_{3-}-95 \%$ Recommended dose of nitrogen (RDN) through NCU + Recommended dose of Phosphorus and Potassium (RDP and $\mathrm{K})(7795 \mathrm{~kg} / \mathrm{ha})$. Lowest grain yield was recorded in $\mathrm{T}_{8^{-}} 0$ Nitrogen + Recommended dose of Phosphorus and Potassium (RDP and K) (Control) (2947 kg/ha) (Table.1). Shivay et al., (2000) ${ }^{[13]}$ and Sugunya et al., (2007) ${ }^{[17,18]}$ also recorded more grain and straw yields from NCU application at $80 \%$ 
level, the yield was reduced significantly. Neem coated urea provide a nitrogen release pattern that is more likely to match the crop growth and nitrogen demand and therefore these fertilizers are likely to give higher yield and nitrogen use efficiency. These results are reported by Heitor et al., (2018) [3].

The straw yield recorded significantly higher in $\mathrm{T}_{2}-\mathrm{RDF} 120$ 60-40 $\mathrm{N}$ through Neem coated urea (NCU) $(8029 \mathrm{~kg} / \mathrm{ha})$ as compared to $\mathrm{T}_{4}-90 \%$ Recommended dose of nitrogen (RDN) through NCU + Recommended dose of Phosphorus and Potassium (RDP and K) (8449 kg/ha), $\mathrm{T}_{5-} \quad 85 \%$ Recommended dose of nitrogen (RDN) through NCU + Recommended dose of Phosphorus and Potassium (RDP and K) $(8216 \mathrm{~kg} / \mathrm{ha}), \mathrm{T}_{6}-80 \%$ Recommended dose of nitrogen (RDN) through NCU + Recommended dose of Phosphorus and Potassium (RDP and K) (7848 kg/ha), $\mathrm{T}_{7-} \quad 75 \%$ Recommended dose of nitrogen (RDN) through NCU + Recommended dose of Phosphorus and Potassium (RDP and K) $(7348 \mathrm{~kg} / \mathrm{ha}) . \mathrm{T}_{8}-0$ Nitrogen + Recommended dose of Phosphorus and Potassium (RDP and K) (Control) (4009 $\mathrm{kg} / \mathrm{ha}$ ) and it remained comparable with $\mathrm{T}_{1}-\mathrm{RDF} 120-60-40$ $\mathrm{N}$ through Prilled urea (PU) (9063 kg/ha), $\mathrm{T}_{3-}-95 \%$ Recommended dose of nitrogen (RDN) through NCU + Recommended dose of Phosphorus and Potassium (RDP and $\mathrm{K})(9334 \mathrm{~kg} / \mathrm{ha})$. Lowest grain yield was recorded in $\mathrm{T}_{8^{-}} 0$ Nitrogen + Recommended Dose of Phosphorus and Potassium (RDP and K) (Control) (4009 kg/ha). Nitrogen influenced vegetative growth in terms of plant height, number of tillers $/ \mathrm{m}^{2}$ which increased straw yield. It might be due to increased nitrogen use efficiency and continuous supply of nitrogen boosting vegetative growth (Table.1). Singh and Shivay (2003) ${ }^{[13]}$ found significantly higher grain and straw yield as compared to prilled urea. Sarangi et al., (2016) ${ }^{[12]}$ also found similar results. Mangat and Narang (2004) [7] found $100 \%$ recommended levels of neem coated urea gave significantly higher yield in wheat when NCU was applied at $80 \%$ level the yield was reduced significantly.

\section{Effect of neem coated urea on Total nutrient uptake in rice}

The total nutrient uptake was influenced significantly with application of nitrogen either in the form of neem coated urea or prilled urea as compared to non application of nitrogen with recommended dose of phosphorus and potassium (Table.2).

Nitrogen uptake recorded significantly higher in $T_{2}-R D F$ 120-60-40 N through Neem coated urea (NCU) $(104.0 \mathrm{~kg} / \mathrm{ha})$ over $\mathrm{T}_{4}-90 \%$ Recommended dose of nitrogen (RDN) through $\mathrm{NCU}+$ Recommended dose of Phosphorus and Potassium (RDP and K) $(84.0 \mathrm{~kg} / \mathrm{ha}), \mathrm{T}_{5}-85 \%$ Recommended dose of nitrogen (RDN) through NCU + Recommended dose of Phosphorus and Potassium (RDP and K) $(78.5 \mathrm{~kg} / \mathrm{ha}), \mathrm{T}_{6}-80 \%$ Recommended dose of nitrogen (RDN) through NCU + Recommended dose of Phosphorus and Potassium (RDP and K) $(72.6 \mathrm{~kg} / \mathrm{ha}), \mathrm{T}_{7-}-75 \%$ Recommended dose of nitrogen (RDN) through NCU + Recommended dose of Phosphorus and Potassium (RDP and K) $(68.3 \mathrm{~kg} / \mathrm{ha}) . \mathrm{T}_{8^{-}} 0$ Nitrogen + Recommended dose of Phosphorus and Potassium (RDP and K) (Control) (48.6 kg/ha) and it remained comparable with $\mathrm{T}_{1}$ - RDF 120-60-40 N through Prilled urea (PU) (97.6 kg/ha), $\mathrm{T}_{3}-95 \%$ Recommended dose of nitrogen (RDN) through $\mathrm{NCU}+$ Recommended dose of Phosphorus and Potassium (RDP and K) (98.2 kg/ha). Lowest nitrogen uptake was recorded in $\mathrm{T}_{8^{-}} 0$ Nitrogen + Recommended dose of
Phosphorus and Potassium (RDP and K) (Control) (48.6 $\mathrm{kg} / \mathrm{ha}$ ) (Table.2).

In case of phosphorus uptake, significantly higher $\mathrm{T}_{2}-\mathrm{RDF}$ 120-60-40 N through Neem coated urea (NCU) $(19.0 \mathrm{~kg} / \mathrm{ha})$ over $\mathrm{T}_{4}-90 \%$ Recommended dose of nitrogen (RDN) through $\mathrm{NCU}+$ Recommended dose of Phosphorus and Potassium (RDP and K) (15.5 kg/ha), $\mathrm{T}_{5}-85 \%$ Recommended dose of nitrogen (RDN) through NCU + Recommended dose of Phosphorus and Potassium (RDP and K) (14.6 kg/ha), T $6-80 \%$ Recommended dose of nitrogen (RDN) through NCU + Recommended dose of Phosphorus and Potassium (RDP and K) $(13.8 \mathrm{~kg} / \mathrm{ha}), \mathrm{T}_{7-}$ 75\% Recommended dose of nitrogen (RDN) through NCU + Recommended dose of Phosphorus and Potassium (RDP and K) $(12.6 \mathrm{~kg} / \mathrm{ha}) . \mathrm{T}_{8^{-}} 0$ Nitrogen + Recommended dose of Phosphorus and Potassium (RDP and $\mathrm{K})($ Control) $(10.2 \mathrm{~kg} / \mathrm{ha})$ and it remained comparable with $\mathrm{T}_{1}$ - RDF 120-60-40 N through Prilled urea (PU) (18.7 kg/ha), $\mathrm{T}_{3^{-}}$95\% Recommended dose of nitrogen (RDN) through $\mathrm{NCU}+$ Recommended dose of Phosphorus and Potassium (RDP and K) (18.2 kg/ha). Lowest phosphorus was recorded in $\mathrm{T}_{8^{-}} 0$ Nitrogen + Recommended dose of Phosphorus and Potassium (RDP and K) (Control) (10.2 kg/ha) (Table.2).

Potassium uptake was significantly higher in $\mathrm{T}_{2}-\mathrm{RDF} 120$ $60-40 \mathrm{~N}$ through Neem coated urea (NCU) $(107.0 \mathrm{~kg} / \mathrm{ha})$ over $\mathrm{T}_{4^{-}}$90\% Recommended dose of nitrogen (RDN) through NCU + Recommended dose of Phosphorus and Potassium (RDP and K) $(96.0 \mathrm{~kg} / \mathrm{ha}), \mathrm{T}_{5}-85 \%$ Recommended dose of nitrogen (RDN) through NCU + Recommended dose of Phosphorus and Potassium (RDP and K) $(92.0 \mathrm{~kg} / \mathrm{ha}), \mathrm{T}_{6}-80 \%$ Recommended dose of nitrogen (RDN) through NCU + Recommended dose of Phosphorus and Potassium (RDP and K) $(88.0 \mathrm{~kg} / \mathrm{ha}), \mathrm{T}_{7-}-75 \%$ Recommended dose of nitrogen (RDN) through NCU + Recommended dose of Phosphorus and Potassium (RDP and K) (83 kg/ha). T $_{8-} 0$ Nitrogen + Recommended dose of Phosphorus and Potassium (RDP and $\mathrm{K})$ (Control) $(42.0 \mathrm{~kg} / \mathrm{ha})$ and it remained comparable with $\mathrm{T}_{1}$ - RDF 120-60-40 N through Prilled urea (PU) (104.0 $\mathrm{kg} / \mathrm{ha}$ ), $\mathrm{T}_{3^{-}}-95 \%$ Recommended dose of nitrogen (RDN) through NCU + Recommended dose of Phosphorus and Potassium (RDP and K) (101.0 kg/ha). Lowest nitrogen uptake was recorded in $\mathrm{T}_{8^{-}} 0$ Nitrogen + Recommended dose of Phosphorus and Potassium (RDP and K) (Control) (42.0 $\mathrm{kg} / \mathrm{ha}$ ) (Table.2). The balanced nutrition led to better uptake of all the nutrients. Raj et al., (2014) ${ }^{[11]}$ found that neem cake blended urea maintained high available nutrient status in the soil compared to other slow release forms of urea with regard to different nutrient sources, neem cake blended urea recorded the highest uptake. Upadhyay and Tripathi (2000) ${ }^{[20]}$, Shivay et al. (2000) [13] and Thind et al., (2010) also found superiority of NCU over ordinary urea in nitrogen uptake and nitrogen use efficiency.

\section{Effect of neem coated urea on Economics in rice}

Higher net returns and benefit cost ratio was realized in $\mathrm{T}_{2}$ RDF 120-60-40 $\mathrm{N}$ through Neem coated urea (NCU), $\mathrm{T}_{3}-$ 95\% Recommended dose of nitrogen (RDN) through NCU+ Recommended dose of Phosphorus and Potassium (RDP and $\mathrm{K})$ and $\mathrm{T}_{1}-\mathrm{RDF}$ 120-60-40 $\mathrm{N}$ through Prilled urea (PU), though cost of cultivation was high, it's mainly because of higher grain and straw yields obtained in these treatments. Lowest benefit cost ratio was observed in

$\mathrm{T}_{8^{-}} 0$ Nitrogen + Recommended dose of Phosphorus and Potassium (RDP and K) (Control) (Table-3). 
Table 1: Growth, yield attributes and yield of rice as influenced by neem coated urea

\begin{tabular}{|c|c|c|c|c|c|c|c|c|}
\hline Treatments & $\begin{array}{c}\text { Plant } \\
\text { height } \\
(\mathbf{c m})\end{array}$ & $\begin{array}{c}\text { Tillers } \\
\left(\mathbf{N o} / \mathbf{m}^{2}\right)\end{array}$ & $\begin{array}{r}\text { Panicles } \\
\left(\mathbf{N o} / \mathbf{m}^{2}\right)\end{array}$ & $\begin{array}{c}\text { Panicle } \\
\text { length } \\
\text { (cm) }\end{array}$ & $\begin{array}{c}\text { Panicle } \\
\text { weight } \\
\text { (g) }\end{array}$ & $\begin{array}{l}\text { Test } \\
\text { wt. } \\
\text { (g) }\end{array}$ & $\begin{array}{c}\text { Grain } \\
\text { yield } \\
\text { (kg/ha) }\end{array}$ & $\begin{array}{c}\text { Straw } \\
\text { yield } \\
\text { (kg/ha) }\end{array}$ \\
\hline T1- RDF 120-60-40 N through prilled urea & 103.0 & 379.0 & 344.0 & 26.9 & 4.3 & 11.89 & 7565 & 9063 \\
\hline T2- RDF 120-60-40 N through neem coated urea & 103.7 & 392.7 & 357.7 & 27.9 & 4.5 & 12.75 & 8029 & 9620 \\
\hline T3- 95\%RDN through neem coated urea +RD P and K & 103.0 & 385.0 & 354.3 & 27.3 & 4.4 & 12.17 & 7795 & 9334 \\
\hline T4- 90\%RDN through neem coated urea +RD P and $\mathrm{K}$ & 102.3 & 362.7 & 337.0 & 26.8 & 4.1 & 11.97 & 7052 & 8449 \\
\hline T5- 85\%RDN through neem coated urea + RD P and K & 102.0 & 343.0 & 320.7 & 26.4 & 4.0 & 11.97 & 6754 & 8216 \\
\hline T6- $80 \%$ RDN through neem coated urea +RD P and $\mathrm{K}$ & 101.7 & 333.0 & 305.3 & 26.1 & 4.0 & 11.61 & 6442 & 7848 \\
\hline T7- 75\%RDN through neem coated urea +RD P and K & 101.3 & 316.0 & 286.3 & 25.3 & 3.9 & 11.24 & 5983 & 7348 \\
\hline T8 - 0N+RD P and K & 81.7 & 196.7 & 168.0 & 20.7 & 1.3 & 10.24 & 2947 & 4009 \\
\hline $\mathrm{SEm} \pm$ & 0.97 & 10.24 & 7.75 & 0.19 & 0.35 & 0.26 & 211 & 255 \\
\hline $\mathrm{CD}(\mathrm{p}=0.05)$ & 2.99 & 31.35 & 23.73 & 0.57 & 1.08 & 0.79 & 647 & 783 \\
\hline
\end{tabular}

Table 2: Total nutrient uptake $(\mathrm{kg} / \mathrm{ha})$ in rice as influenced by neem coated urea

\begin{tabular}{|c|c|c|c|}
\hline Treatments & $\begin{array}{c}\text { Total nitrogen uptake } \\
(\mathbf{k g} / \mathbf{h a})\end{array}$ & $\begin{array}{c}\text { Total phosphorus uptake } \\
(\mathbf{k g} / \mathbf{h a})\end{array}$ & $\begin{array}{c}\text { Total potassium uptake } \\
(\mathbf{k g} / \mathbf{h a})\end{array}$ \\
\hline T1- RDF 120-60-40 N through prilled urea & 97.6 & 18.7 & 104 \\
\hline T2- RDF 120-60-40 N through neem coated urea & 104.0 & 19.0 & 107 \\
\hline T3- 95\%RDN through neem coated urea +RD P and K & 98.2 & 18.2 & 101 \\
\hline T4- 90\%RDN through neem coated urea +RD P and K & 84.0 & 15.5 & 96 \\
\hline T5- 85\%RDN through neem coated urea + RD P and K & 78.5 & 14.6 & 92 \\
\hline T6- 80\%RDN through neem coated urea +RD P and K & 72.6 & 13.8 & 88 \\
\hline T7- 75\%RDN through neem coated urea +RD P and K & 68.3 & 12.6 & 83 \\
\hline T8 - 0N+RD P and K & 48.6 & 10.2 & 42 \\
\hline SEm \pm & 2.31 & 0.80 & \\
\hline CD $(\mathrm{p}=0.05)$ & 7.13 & 2.48 & 2.34 \\
\hline
\end{tabular}

Table 3: Economics of rice as influenced by neem coated urea

\begin{tabular}{|c|c|c|c|c|}
\hline Treatments & Gross returns (Rs/ha) & Cost of cultivation (Rs/ha) & Net returns (Rs/ha) & B:C \\
\hline T1- RDF 120-60-40 N through prilled urea & 126321 & 49,000 & 77321 & 1.57 \\
\hline T2- RDF 120-60-40 N through neem coated urea & 134069 & 50,000 & 84069 & 1.68 \\
\hline T3- 95\%RDN through neem coated urea +RD P and K & 130162 & 49,600 & 80562 & 1.62 \\
\hline T4- 90\%RDN through neem coated urea +RD P and $\mathrm{K}$ & 117755 & 49,200 & 68555 & 1.39 \\
\hline T5- 85\%RDN through neem coated urea + RD P and K & 112779 & 48,800 & 63979 & 1.31 \\
\hline T6- 80\%RDN through neem coated urea +RD P and K & 107569 & 48,400 & 59169 & 1.22 \\
\hline T7- 75\%RDN through neem coated urea +RD P and $\mathrm{K}$ & 99905 & 48,000 & 51905 & 1.08 \\
\hline T8 - 0N+RD P and K & 49209 & 46,000 & 3209 & 0.06 \\
\hline
\end{tabular}

\section{Conclusion}

On the basis of the results obtained from the present investigation, it is conducted that neem coated urea found to be beneficial in improving the growth parameters, yield attributing characters and yield of rice. Experimental findings indicate that $\mathrm{T}_{3}-95 \%$ Recommended dose of nitrogen (RDN) through NCU + Recommended dose of Phosphorus and Potassium (RDP and K), with 5\% reduction in recommended nitrogen in the form of neem coated urea (NCU) produced the comparable grain yields which were obtained in $\mathrm{T}_{2}-\mathrm{RDF}$ 120-60-40 N through Neem coated urea (NCU) and $\mathrm{T}_{1}-\mathrm{RDF}$ 120-60-40 $\mathrm{N}$ through Prilled urea (PU) with $100 \%$ recommended nitrogen either in the form of NCU or PU respectively.

Hence, $\mathrm{T}_{3}-95 \%$ Recommended dose of nitrogen (RDN) through NCU + Recommended dose of Phosphorus and Potassium (RDP and K), found to be better with 5\% saving of recommended nitrogen in the neem coated urea (NCU) form for obtaining higher grain yield.

\section{References}

1. Bains SS, Prasad R, Bhatia PC. Use of indigenous materials to enhance the efficiency of fertilizer nitrogen for rice, Fertilizer News. 1971; 16:30-32
2. Gomez KA, Gomez AA. Statistical Procedures for Agricultural Research, $2^{\text {nd }}$ Edition. John Wiley and Sons. New York.1984, 639

3. Heitor cantarella, Rafael Otto, Johny Rodrigues soares, Ajino Gomes de Brio silva. Agronomic efficiency of NBPT as a urease inhibitor: A review. Journal of advanced Research. 2018; 13:19-27.

4. Kumar Dinesh, Kumar C Deva, Kumar Rajesh, Das aurovinda, Panner Selvam P, Shivay YS. Relative efficiency of prilled urea coated with major neem (Azadirachta indica A. Juss) oil composition in low land irrigated rice of indogangetic plains. Archieves of Agronomy and Soil science. 2011; 57:61-74.

5. Kumar N, Prasad R, Fuzaman. Relative response of high yielding variety and hybrid of rice to levels and sources of nitrogen. Indian nation of science academy. 2007; 73:1-6.

6. Kumar Ravendra, Jaiswal Pawan, Kumar Ajit, Kumar Sunil. Effect of modified urea on nitrogen use efficiency, growth and yield of transplanted rice (Oryza sativa L.) var NDR-359, New Agriculturist. 2015; 26:263-266.

7. Mangat GS, Narang JK. Agronomical trial for efficacy of NFL Neem Coated Urea. Fertilizer Marketing News. 2004; 35(11):1-7. 
8. Olsen SR, Cole CV, Watanabe FS, Dean LA. Estimation of available phosphorus in soil by extraction with sodium bicarbonate USDA Circ. 1954, 939.

9. Prasad R. Fertilizer urea, food security, health and the environment. Current Science. 1998; 75:677-683

10. Pushpanathan KR, Vijayaa Kumar M, Siddeswaran K. Effect of forms of fertilizer nitrogen and timing of application on growth and yield of rice (Oryza sativa L.). Agriculture Review. 2015; 2:153-156.

11. Raj SK, Bindhu JS, Girjadevi L. Nitrogen availability and uptake as influenced by time of application and $\mathrm{N}$ sources in semidry rice (Oryza sativa L.). Journal of Crop and weed. 2014; 10:295-302.

12. Sarangi SK, Maji B, Singh S, Srivastava AK, Singh US, Sharma DK. Nitrogen management through neem coated urea and application method further improve rice productivity in coastal flood prone rainfed low land, $4^{\text {th }}$ Inernational Agronomy Congress, New Delhi. 2016; 2:22-26.

13. Shivay YS, Prasad R, Singh S. Effect of nitrogen levels and neem oil emulsions coated urea on growth, yield attributes and yield of Wetland rice. In: Extended Summary of International Conference on managing Natural Resources. New Delhi ICAR. 2000; 3:13401342.

14. Singh S, Shivay YS. Coating of prilled urea with eco friendly neem (Azadirachta indica A Juss) formulations for efficient nitrogen use in hybrid rice. Acta Agronomica Hungarica. 2003; 2:22-26.

15. Statistical Year Book. Directorate of Economics and Statistics, Government of Telanagana, Hyderabad. 2015.

16. Subbaiah BV and Asija GL. Rapid procedure for determination of available nitrogen in soils. Current Sci., 1956; 31:196.

17. Suganya S, Appavi K, Vadivel A. Nitrogen release pattern of neem coated urea products in flood water. An Agriculture Journal of Soil science. 2007; 2:128-133.

18. Suganya S, Appavi K, Vadivel A. Relative efficiency of neem coated products for rice grown in different soils. An Agriculture Journal of Soil science. 2007; 2:29-34.

19. Thind HS, Singh Bijay Pannu, Singh RPS, Yadvinder Singh, Varinderpal Gupta, Vashista RK. Relative performance of neem coated urea vis-à-vis ordinary urea applied to rice on the basis of soil test or following need based nitrogen management using leaf colour chart. Nutritional cycling in Agro ecosystems. 2010; 87:1-8.

20. Upadhyay SK, Tripathy KS. Response of prilled and neem extract coated urea application timings to rice (Oryza sativa L.). Agricultural Science Digest. 2000; 20(2):84-86.

21. Yadav Abhineet. Comparative Effect of prilled urea and Neem Coated Urea on plant available Forms of Nitrogen in Rice (Oryza sativa L.). Dept of Soil Science and Agricultural Chemistry, Thesis Submitted to Bihar Agricultural University, Sabour, 2017. 